\title{
Thoughts for a new Secretary
}

Dear John,

You have just over a week before you take over one of the toughest medicopolitical jobs in Britain, so may I suggest that you sing carols, read your favourite Parson Woodforde's Diary, and get all the rest you can before reading this letter over Hogmanay rather than after the Christmas turkey and pudding ? You must have had so much advice by now that I hope you won't take it amiss if somebody else offers his.

Let's start with the credits: the BMA is in better shape than it has been for some time-and, as I'm sure you'll agree, Elston Grey-Turner has greatly contributed to this improvement. We're fortunate in having a team of chief officers with a blend of vigour and experience; having abandoned the idea that any doctor can do anything and that one is needed in every senior post, the BMA now has a permanent staff with a first-rate squad of experts on subjects such as law, economics, and industrial relations; communications with the profession have been expanded; and a couple of years ago who could have believed that our peripheral structure, with its IROs and POWARS would be so strong? So today, I believe, the BMA is in an even better position to claim that only it can authoritatively represent the whole profession and cope with the immense burdens.

Firstly, the federal structure, so heatedly debated a few years ago, is working. So to its credit the Association has retained the juniors rather than watch them angrily depart into an organisation of their own. Secondly, necessary though medical ginger groups are, there is little sign of any of them becoming more than that. No group is an island and I welcome the signs that the consultants and academics now realise that the Association is not run by GPs for GPs, that its apparent slowness is due to ultra-democracy (often forced on a particular group of doctors by suspicious colleagues), and that only by thrashing out a problem together with comments by other interested parties can you get a decision that will work. Finally the BMA is continuing to have a unique and important voice in medicine-on seat-belts, drink driving laws, and abortion, for instance. In the issue of computers and confidentiality who else had the authority, the resources, or the skill in press relations to raise a major public furore, and to get the right results?

In the end, though, people in 1990 are going to judge your reign on how well the BMA has coped with three things: balance, inflation, and ensuring that doctors retain responsibility for patients. By balance I mean the subtle administrative checks and influences that often make the difference between success and failure: what decisions are best taken by medical officials and what by non-medical ones; weighing the influences of the periphery and the centre; ensuring that the power of a committee is related to its numbers in the NHS and not to the stridency of its individual voices; retaining the authority of the secretariat while maintaining the senior members' legitimate role in making policy; and, most difficult of all, being an effective trade union without destroying professional values.

All this is difficult enough, but inflation may well kill us if we are not careful. You have championed functional budgeting, and committees will have to stick to their allocations, though I can see you wasting much time resisting inevitable demands for new subcommittees and working parties when no corresponding saving is planned. But we will have to save more than that; everybody has his own pet views (close the dining room; leave the WMA; shut one Scottish office are the "ongoing boring situations"), but they are mostly savings of only a few tens of thousands of pounds. If we are to save hundreds of thousands, as we must by the mid ' 80 s, my personal view is that the BMA must consider getting the bulk of the administration out of London to cheaper, modern accommodation where recruiting staff is both easier and less costly.

Even so, there is another side to any budget: income. Many of the BMA's financial troubles come not only from inflation but also from having to implement necessary but expensive decisions by the Representative Body, such as a stronger regional structure. So, inevitably subscriptions must rise and members will be tempted to resign and free ride on somebody else. Somehow we have to make membership of the BMA as essential as that of the defence bodies, and I am afraid, John, that it may be your job to tell them that they must not do what is the work of the Association and to devise some new scheme whereby our roles can be linked. Doctors must be convinced that only the BMA has the staff and experience to protect their professional lives in an increasingly "industrialised" NHS.

I am, however, optimistic that you will succeed, so finally I trust that you will have time to anticipate where medicine is going. Of course, we must help with the details of re-reorganisation, but we should be able to offer more than that. Audit, cost-effectiveness, priorities will continue to be important subjects of debate, and there are going to be others where the Board of Science-another little-publicised BMA success story-will have its usual invaluable advisory role. But I should also like to see the Association take a leaf out of Margaret Thatcher's book and suggest where some of the worst practices of a State monopoly can be righted by giving certain aspects to private enterprise. To take only our hospitals, why are they so filthy? Why is the food often still so awful? Why do we have so many porters lolling around doing nothing, while our nurses are, if anything, working harder than ever? Perhaps if you reconstituted the BMA Planning Unit-my financial quid pro quo would be cateringthey would tell us and the public how to make a fresh start. Be that as it may, you start with three advantages: the good will of the staff; great experience; and a razor-sharp intellect, which makes you as acceptable at WHO as at Whitley, at the royal colleges as at COHSE, and at the Department as at the divisions. Have a good decade.-SCRUTATOR. 